\title{
JUDICIAL REVIEW AND THE SUPREME COURT IN INDONESIA: A NEW SPACE FOR LAW?
}

\section{Simon Butt and Nicholas Parsons}

In his 2013 New Year's speech, the mayor of Lhokseumawe, Aceh, Suaidi Yahya, announced that his administration would enact a bylaw (peraturan daerah, or Perda) that prohibited women from straddling motorcycles as pillion passengers. The bylaw would require that women sit sideways on motorbikes unless they were driving. According to Yahya, the bylaw would prevent females from spreading their legs in public. Male drivers would thereby not be "provoked," and women would be protected "from undesirable conditions." ${ }^{1}$ According to Yusuf A. Samad, a member of Lhokseumawe Legislative Council, straddling a motorbike accentuates a woman's curves, and "showing the curves of a woman's body is against Sharia." ${ }^{2}$

While this proposed bylaw drew praise from Indonesia's conservative Council of Islamic Scholars (Majelis Ulama Indonesia), ${ }^{3}$ it heightened concerns about the increasing numbers of laws enacted by local governments throughout Indonesia that appear to violate human rights provided by Indonesia's Constitution and national statutes. ${ }^{4}$ In 2010, the National Human Rights Commission (Komisi Nasional Hak Asasi Manusia, Komnas HAM) identified approximately 3,200 Perda as breaching the

\footnotetext{
${ }^{1}$ Fitri Bintang Timur, "To Straddle or Not to Straddle, That Is the Question," Jakarta Post, January 7, 2013.

${ }^{2}$ Bagus BT Saragih and Hotli Simanjuntak, "Aceh City to Ban Women from Straddling Motorbikes," Jakarta Post, January 3, 2013; Lynda Ibrahim, "Urban Chat: Straddle On, Strong Sisters," Jakarta Post, January 4, 2013.

3 “MUI Supports Aceh Bylaw Banning Females from Straddling Motorcycles," Jakarta Globe, January 8, 2013.

${ }^{4} 1945$ Constitution, Chapter XA; Law No 39 of 1999 on Human Rights.
} 
human rights of minorities, particularly the freedom from discrimination. ${ }^{5}$ The Human Rights Research and Development Body of the Law and Human Rights Ministry found that most local government laws lacked a "human rights perspective" and that only around 5 percent of bylaws aimed to assist ordinary citizens (masyarakat kecil). ${ }^{6}$

Komnas Perempuan (the National Commission on Violence against Women) has recently identified 282 bylaws that, either in their terms or their application, discriminated against women as of August 2012, up from 207 in 2011, 189 in 2010, and 154 in 2009. ${ }^{7}$ According to Komnas Perempuan, around one hundred of these bylaws concerned prostitution and pornography, sixty imposed dress codes and religious standards, and thirty-eight restricted women's mobility. These bylaws were issued by local governments in hundreds of regencies across twenty-eight of Indonesia's thirtyfour provinces. In Aceh, some of these bylaws were enforced through imposition of draconian sanctions, including "punching, being bathed with sewage water, public parading, destruction of property, [and] evictions." ${ }^{8}$

Some of these discriminatory bylaws seek to impose Islamic values and are, therefore, often labeled by the media and commentators as Perda Syariah. ${ }^{9}$ Most of them appear to fall into one of two categories. ${ }^{10}$ In the first category are laws that, while consistent with Islamic teachings, concern activities or behaviors nonetheless regulated in most societies, whether religious or secular. In this category are public order laws regulating alcohol, ${ }^{11}$ gambling, ${ }^{12}$ and prostitution. ${ }^{13}$ In the second category are laws more obviously and uniquely Islamic in inspiration. They include laws promoting

\footnotetext{
5 “3200 Perda Bertentangan Dengan HAM," Media Indonesia, July 7, 2010.

6 "Hanya Lima Persen Perda Berperspektif HAM," Hukumonline, January 11, 2008.

${ }^{7}$ Ina Parlina and Margareth Aritonang, "After Straddling Proposal, Ministry to Review Bylaws," Jakarta Post, January 18, 2013.

8 "An Uphill Battle to End Discriminatory Laws," Jakarta Post, September 17, 2012.

${ }^{9}$ Robin Bush, "Regional 'Sharia' Regulations in Indonesia: Anomaly or Symptom?" in Indonesia: Islamic Life and Politics, ed. Greg Fealy and Sally White (Canberra: Indonesia Update Series, 2008); Arskal Salim, Challenging the Secular State: The Islamization of Law in Modern Indonesia (Honolulu, HI: University of Hawaii Press, 2008); Arskal Salim and Azyumardi Azra, Shari'a and Politics in Modern Indonesia (Singapore: Institute of Southeast Asian Studies, 2003).

${ }^{10}$ Arskal Salim, "Muslim Politics in Indonesia's Democratisation: The Religious Majority and the Rights of Minorities in the Post-New Order Era," in Indonesia: Democracy and the Promise of Good Governance, ed. Ross H. McLeod and Andrew J. MacIntyre, Indonesia Update Series (Singapore: Institute of Southeast Asian Studies, 2007); Melissa Crouch, Indonesia, Militant Islam, and Ahmadiyah: Origins and Implications (Melbourne: ARC Federation Fellowship Centre of Islamic Law and Society, Melbourne Law School, University of Melbourne, 2009); Nicholas Parsons and Marcus Mietzner, "Sharia By-laws in Indonesia: A Legal and Political Analysis," Australian Journal of Asian Law 11,2 (2010): 190. Note, however, that the categories we use here differ from the categories used in other scholarly works. Arskal Salim, for instance, groups such Perda into three categories: public order, religious skills and duties, and religious symbolism. Melissa Crouch recognizes nine categories: clothing, prostitution, social problems, alcohol and drugs, religious obligations, zakat management, Qur'anic education, the implementation of syariah, and nonIslamic religious regulations. However, some of these categories- "social problems" and "alcohol and drugs," for instance, and "religious obligations," "zakat management," and "implementation of syariah" appear to overlap. For the purpose of determining whether these bylaws are within a regional government's jurisdiction, we distinguish between those that can only be justified on religious grounds and those that have a broader (secular) justification.

${ }^{11}$ For example, Perda of Banjarmasin City No. 6 of 2007.

${ }^{12}$ For example, Perda of Sambas City No. 4 of 2004.

${ }^{13}$ For example, Perda of Tangerang City No. 8 of 2005.
} 
Quranic literacy; ${ }^{14}$ prohibiting eating in public during Ramadan; ${ }^{15}$ imposing Islamic dress codes, ${ }^{16}$ including upon non-Muslim women; ${ }^{17}$ and regulating Islamic charitable donations (zakat). ${ }^{18} \mathrm{~A}$ third category, which are Islam-related but do not seek to establish Islamic norms, are those that discriminate against, or even ban, followers of Ahmaddiyah, an oft-persecuted minority Muslim sect. ${ }^{19}$

Among the criticisms of Perda Syariah is that they breach Indonesia's human rights obligations. ${ }^{20}$ The primary domestic source of these obligations is now Indonesia's Bill of Rights, inserted into the Constitution in 2000. This is a large catalogue of rights, drawn from the main international human rights treaties, including the Universal Declaration of Human Rights, the International Covenant on Civil and Political Rights (ICCPR), and the International Covenant on Social and Economic Rights (ICSER), all of which Indonesia has ratified. ${ }^{21}$ Proponents of Perda Syariah counter that such laws are a legitimate expression of the democratic will of regional communities and a natural consequence of regional autonomy in majority Muslim areas. In this article, we do not seek to examine whether these Perda do, in fact, breach human rights standards, as critics claim. Indeed, our primary concern is not on the propriety or otherwise of Perda Syariah. Rather, we use the example of Perda Syariah-perhaps the most notorious category of what the media have termed "problematic" Perda 22 - to highlight some of the legal and political issues that arise from local lawmaking. The main purpose of this article is to examine the primary mechanism by which citizens can challenge the legality of all types of Perda-judicial review by the Supreme Court (Mahkamah Agung) of Indonesia-and highlight its many legal and practical deficiencies. The result of these deficiencies is that even bylaws that authorize local governments to perpetrate the most egregious breaches of human rights are likely to escape real judicial scrutiny and invalidation. Put simply, the Supreme Court cannot always be relied upon to enforce those or any other rights. This significantly endangers Indonesia's ability to uphold the rights provided in the Indonesian Constitution and domestic laws, and by international treaties it has ratified.

\footnotetext{
${ }^{14}$ For example, Perda of South Pesisir District No. 8 of 2004.

${ }^{15}$ For example, Perda of Banjarmasin City No. 13 of 2003.

${ }^{16}$ For example, Perda of Lima Puluh District No. 5 of 2003.

${ }^{17}$ Yuli Tri Suwarni, "Tasikmalaya to Make Muslim Women Wear Headscarves," Jakarta Post, June 5, 2012.

${ }^{18}$ For example, Perda of Parepare City No. 1 of 2007.

${ }^{19}$ For an extensive list of the bylaws relating to Ahmaddiyah, see Melissa Crouch, "Judicial Review and Religious Freedom: The Case of Indonesian Ahmadis," Sydney Law Review 34,3 (2012): 545; Crouch, Indonesia, Militant Islam, and Ahmadiyah.

${ }^{20}$ Ahmad Suaedy, Religiously Nuanced Local Regulations and the Future of Indonesian Democracy: An Outline (Jakarta: Wahid Institute, 2008); Siti Musdah Mulia, "Peminggiran Perempuan Dalam Perda Syariat," Tashwirul Afkar 20 (2007); Parsons and Mietzner, "Sharia By-laws in Indonesia"; Melissa Crouch, "Regional Regulations in Indonesia: Failing Vulnerable Groups," Review of Indonesian and Malaysian Affairs 43,2 (2009), Bush, "Regional 'Sharia' Regulations in Indonesia"; Subair Umam, "Pluralisme, Politik, Dan Gerakan Formalisasi Agama: Catatan Kritis Atas Formalisasi Agama Di Maros Dan Pangkep," in Politisasi Agama Dan Konflik Komunal, ed. Ahmad Suaedy (Jakarta: Wahid Institute, 2007).

${ }^{21}$ Laws 11 of 2005 (ICESCR) and 12 of 2005 (ICCPR).

${ }^{22}$ See, for example, "ICW: 84 Hakim Tipikor Dinilai Bermasalah," Hukumonline, August 29, 2012; "Hingga Akhir 2008, 34 Perda Bermasalah," Kompas, December 31, 2008; "Perda Bermasalah," Koran Jakarta, August 12, 2010; "Perda Bermasalah Lambat Ditangani," Seputar Indonesia, July 13, 2010.
} 


\section{Politics and Law}

The analytical framework employed in this article is primarily legal. Yet conventional wisdom has long held that Indonesian law as it appears "on paper" is quite different from its "practice"-that is, its operation or implementation, particularly by the courts. A large body of literature, produced by both political scientists and legal scholars, has convincingly demonstrated that law "in practice" is dictated almost exclusively by non-legal factors-predominantly politics, corruption, and "legal culture." ${ }^{23}$ The result is that the law "on paper" is often either ignored or misapplied in favor of the highest bidder (in cases involving at least one non-state actor, whether an individual or legal entity) or the state (in cases involving the government and even individual officials). This explanation of law as "power" (whether political or financial) was largely developed from analyses of the operation of the legal system as it existed before the fall of Suharto in 1998, primarily based on studies of disputes between private parties (such as commercial matters) and between the citizen and state (such as criminal and administrative law cases).

We argue that, while this explanation certainly remains broadly applicable in modern Indonesia-particularly given the continuing, perhaps even increasing, influence of corruption in many types of cases-it no longer appears accurately to describe the operation of the legal system in all cases. In some types of cases, corruption appears unlikely to be in play, and the law seems able to constrain the exercise of political power, at least to some degree.

The types of cases in which law is becoming more relevant are, broadly speaking, disputes between the various institutions of government about their relative jurisdictions. Some of these disputes have played out in Indonesia's Constitutional Court, about which much has been written. ${ }^{24}$ This article takes a different line of enquiry, examining the jurisdictional disputes between central and regional governments that have been decided by the Indonesian Supreme Court. These disputes have emerged with increasing regularity since regional autonomy was introduced posthaste after the end of the New Order.

They are, in our view, essentially "new" disputes. In them, the Indonesian state, represented by the central government and a regional government, is, in essence, fighting itself. This is true even in cases brought before the Supreme Court by citizens affected by what they consider to be an undesirable Perda. Although, as mentioned below, they must be affected by the Perda to have standing to bring a claim before the Supreme Court, the concrete circumstances in which they find themselves are irrelevant to the Court's enquiry. Even in these judicial review cases, the court's task is to determine whether a national law trumps a local law. Not surprisingly, Indonesian

${ }^{23}$ Daniel S. Lev, "Judicial Institutions and Legal Culture in Indonesia," in Culture and Politics in Indonesia, ed. Claire Holt (Ithaca, NY: Cornell University Press, 1972); Daniel S. Lev, "Judicial Authority and the Struggle for an Indonesian Rechtsstaat," Law and Society Reviewo 13 (1978): 37-71; Sebastiaan Pompe, The Indonesian Supreme Court: A Study of Institutional Collapse (Ithaca, NY: Cornell Southeast Asia Program Publications, 2005); Adriaan Bedner, Administrative Courts in Indonesia: A Socio-Legal Study (The Hague and Boston, MA: Kluwer Law International, 2001); Tim Lindsey, ed., Indonesia: Law and Society, 2nd ed. (Annandale, NSW: Federation Press, 2008)

${ }^{24}$ Simon Butt, "Indonesia's Constitutional Court-The Conservative Activist or Pragmatic Strategist?" in The Judicialization of Politics in Asia, ed. Björn Dressel (Oxfordshire, and New York, NY: Routledge, 2012). 
government institutions, including the national and regional governments, have had serious rivalries and disagreements throughout Indonesia's modern history. During the Suharto period, at least, these were largely resolved by the might of the central government, backed, of course, by military force or the threat thereof and reinforced by an integrality ideology. ${ }^{25}$ However, since Suharto's fall, the political and legal power previously held in the presidency has been effectively dispersed among a range of institutions, including parliaments, courts, and local administrations. ${ }^{20}$ The Indonesian "state" is, therefore, no longer synonymous with the Indonesian presidency, or even the national government.

These new types of disputes are also taking place in a very different context compared to that in which the "law in practice" and "law as power" explanations were developed. Significantly, under the so-called satu atap (one roof) reforms, the Supreme Court has since been made institutionally independent of the "state" - that is, national government departments-and is said to have been exercising that independence. ${ }^{27}$ Even if the Court were inclined to side with the "government," it is now unclear which institution or tier of government it would side with. As we demonstrate below, in decentralized Indonesia there is genuine disagreement about where real political power lies on the spectrum between the central and regional governments, at least in respect of particular issues that Perda can regulate. One might presume that because the Supreme Court is a national institution, it will naturally side with the central government. However, this presumption is not clearly borne out in the cases, discussed below, in which regional governments have defeated the central government in disputes brought before that Court.

Also important in shaping this new context is the increased transparency of the Supreme Court's decision-making and the publicity these types of cases have attracted. Never before have these disputes played themselves out so publicly in Indonesian courtrooms and been so intensely dissected by the media. Rarely had the decisions themselves been made publicly available, complete with the legal arguments employed by the disputing governments. Many of them are now available on the Supreme Court website.

To be sure, politics are still influential, but the influence appears to have lessened in the post-Suharto period. We argue that, with the increase in judicial independence and greater transparency, the "space" for law has widened in these cases. However, as we shall see, the increasing space for and resort to law has highlighted the significant shortcomings of the law itself. In particular, the rules for delineating the powers and responsibilities of these institutions and for helping resolve disagreements between them are unclear and largely unworkable.

\footnotetext{
${ }^{25}$ Adnan Buyung Nasution, Demokrasi Konstitusional: Pikiran \& Gagasan (Jakarta: Penerbit Buku Kompas, 2010).

${ }^{26}$ Simon Butt and Tim Lindsey, The Indonesian Constitution: A Contextual Analysis (Oxford: Hart, 2012).

${ }^{27}$ Simon Butt and Tim Lindsey, "Unfinished Business: Law Reform, Governance, and the Courts in PostSoeharto Indonesia," in Indonesia, Islam, and Democratic Consolidation, ed. Mirjam Kunkler and Alfred Stepan (New York, NY: Columbia University Press, 2013).
} 


\section{Structure}

We have divided our coverage into four parts. In Part I, we discuss, by way of background, regional governments in Indonesia and the reforms under which they were granted power to enact these bylaws. We also briefly describe the other available mechanism for the review of bylaws- "bureaucratic review." Under this process, the central government examines bylaws and can invalidate them in some circumstances. We then turn to discuss various political and legal issues at play in these disputes. In Part II, we discuss the Supreme Court's jurisdiction to review bylaws, as laid down in the Constitution and national statutes, demonstrating that, at least formally, its jurisdiction is limited. As we shall see, peculiarities of the Indonesian system preclude bylaws being reviewed for compliance with the Constitution, including its Bill of Rights.

Part III examines how the Indonesian Supreme Court has exercised its jurisdiction, through an examination of all forty-six decisions available on the Supreme Court's website in mid-2013 in which the Court reviewed bylaws. These cases fall into two categories. In the first, the Court is asked by a citizen to review the validity of a local law; in the second, a local government asks the Court to challenge the invalidation of a Perda by the central government under the bureaucratic review process we discuss in Part I. In Part IV, we conclude by suggesting ways the Supreme Court could improve its procedures and decision-making in judicial review cases with a view to it becoming a forum in which fundamental domestic and international human rights principles can be reliably upheld. We consider legal arguments that might be used to support the expansion of the Supreme Court's jurisdiction without amending the Indonesian Constitution. Other options-creating an independent body to assess local laws, or handing over jurisdiction to review Perda to the Constitutional Court-are, we argue, legally feasible but undesirable and, in any event, unlikely to be realized in the foreseeable future.

\section{Part I: Regional Autonomy and Bureaucratic Review}

Regional Autonomy

When former President Suharto stepped down in May 1998, Indonesia launched an ambitious program of decentralization. Resentment of Suharto's strongly centralized, predatory, and corrupt state was so strong that many feared Indonesia would "Balkanize" without implementing genuine regional autonomy. Indonesia's national government responded quickly. In 1999, statutes were enacted that required preparations for decentralization to commence by 2001.

One of the priorities of Indonesia's constitutional reforms of 1999-2002 was to entrench the powers of regional governments. Article 18 of the Constitution was amended to grant regional governments in Indonesia's provinces (propinsi), districts (kabupaten), and cities (kota) "the widest possible autonomy," with the central government retaining exclusive jurisdiction over only some areas (Article 18(5)). To this end, local governments were granted lawmaking powers. Democratically elected parliaments (Dewan Perwakilan Rakyat Daerah, or DPRD) at each level of regional government-provincial, city, and district-received legislative powers (Article 18(6) 
of the Constitution) to enact regional legislation (Perda). Democratically elected "regional heads" (kepala daerah)—in provinces, these are governors (gubernur), in districts regents (bupati), and in cities mayors (walikota) -also obtained power to issue their own laws, primarily to implement legislation enacted by their respective parliaments. The laws produced by these local officials are referred to as regional head regulations (peraturan kepala daerah, or perkada). For convenience, in this article we refer generically to both regional legislation and regional head regulations as "bylaws."

At time of writing, Indonesia had 34 provinces, 399 districts, and 98 cities, each with their own legislatures and executive governments, and more than 70,000 villages. ${ }^{28}$ All of these tiers of local government have their own lawmaking individuals and institutions. Although precise numbers appear to be unavailable, these lawmakers have produced many thousands of bylaws, ${ }^{24}$ only a small proportion of which appear on the websites of regional governments and the Ministry of Home Affairs (MOHA) ${ }^{30}$

The primary statute in which Article 18 of the Constitution is fleshed out is Law No. 32 of 2004 on Regional Governance ("the 2004 Regional Governance Law"). Article 10(3) of this Law reserves for the central government exclusive jurisdiction over foreign affairs, defense, internal security, the justice sector, national monetary and fiscal policy, and religion. However, even outside these areas the lawmaking powers of regional governments are not exclusive. Article 10(5) of the 2004 Regional Governance Law gives the central government power to enact laws about matters that fall beyond those reserved exclusively for it. In essence, then, most tiers of Indonesian government have overlapping jurisdiction, except for those areas reserved for the central government. Legally speaking, the central government can, therefore, continue to regulate any matter over which regional governments also have jurisdiction. In other words, the central government is, legally, able to block virtually any regional government law by passing its own higher-level law. However, as we shall see in Part II, jurisdictional overlaps are difficult to resolve within the Indonesian legal system.

\section{Bureaucratic Review}

Indonesia's regional autonomy laws provide for significant oversight by national institutions. One oversight mechanism is bureaucratic review. We provide only a brief outline of this complex process here, given that our focus is judicial review. ${ }^{31}$

The 2004 Regional Governance Law provides two grounds for review of all types of regional laws: noncompliance with the public interest or higher-level laws.

\footnotetext{
${ }^{28}$ We have taken these figures from the Ministry of Home Affairs website, www.depdagri.go.id/, accessed February 5, 2014.

29 "Ribuan Perda Timbulkan Masalah Bagi Pengusaha," Hukumonline, June 23, 2011.

${ }^{30}$ http: / / www.jdih.setjen.kemendagri.go.id/, accessed February 5, 2014.

${ }^{31}$ The review procedures are set out in the 2004 Regional Governance Law (which outlines mechanisms for executive review), Government Regulation No. 79 of 2005 on the Guide to the Supervision of Regional Governance, and MOHA Regulation No. 53 of 2011 on Local Law-making (which provide more details on the review process), and Law No. 28 of 2009 on Regional Taxes and User Charges (which deals specifically with review of laws imposing taxes and user charges). On regional taxes, see Simon Butt and Nicholas Parsons, "Reining in Regional Governments? Local Taxes and Investment in Decentralised Indonesia," Sydney Law Review 34,1 (2012): 91-106.
} 
"Inconsistent with the public interest" is vaguely described in the 2004 Regional Governance Law as "policies that disturb harmonious relations between members of society, public services, and public order and [that are] discriminative." ${ }^{32} \mathrm{We}$ discuss the "higher-level" ground below in Part III.

As for the review process itself, Perda on regional budgets, taxes, user charges (retribusi), and spatial planning must be sent to and approved by the central government before enactment and can be reviewed again after enactment. ${ }^{33}$ Bylaws concerning other matters are subject to post-enactment review only. They must be submitted to the central government for assessment within seven days of enactment. ${ }^{34}$ If they are deemed to violate the public interest or a higher-level law, they are to be invalidated by Presidential Regulation within sixty days of receipt of the Perda for review. ${ }^{35}$ Regional governments then have seven days to cease implementation of the Perda and formally repeal it. ${ }^{36}$ If no Presidential Regulation is issued within the sixtyday time limit, the Perda continues in force by default. ${ }^{37}$ Regional head regulations are reviewed by a similar process, except they can be invalidated by the MOHA rather than the president. ${ }^{38}$

Between 2002 and 2009, the MOHA annulled 1,878 bylaws, and in 2009-12 it cancelled 951 of 15,000 bylaws. ${ }^{39}$ The Home Affairs Minister predicted that his ministry would review more than 2,500 bylaws, both old and new, in $2013 .{ }^{40}$ However, with few exceptions, only Perda that raise revenue for local governments have been targeted for review and invalidation. ${ }^{41}$ Presumably, this focus helps guard central government revenue flows. Laws with other subject matter appear to have escaped review altogether for several reasons. One is that some local governments have refused to send their bylaws to the central government for review, ${ }^{42}$ often as a deliberate strategy

\footnotetext{
${ }^{32}$ Elucidation to Article 136(4).

${ }^{33}$ These are to be sent by governors to the Central Government and by mayors and district heads to provincial governments within three days of their passage through parliament but prior to enactment: MOHA Regulation No. 53 of 2011 Articles 61, 66. Regional governments are to be notified of the outcome of the review within fifteen days, after which the regional government has seven days to make any necessary amendments: MOHA Regulation No. 53 of 2011 Articles 65(1), (2), 70(1), (2).

${ }^{34}$ MOHA Regulation No. 53 of 2011 Articles 73, 75(1), (2).

${ }^{35} 2004$ Regional Governance Law Article 145(2), (3).

${ }^{36} 2004$ Regional Governance Law Article 145(4).

372004 Regional Governance Law Article 145(7).

${ }^{38}$ MOHA Regulation No. 53 of 2011 Article 75(3)

${ }^{39}$ Parlina and Aritonang, "After Straddling Proposal, Ministry to Review Bylaws."

${ }^{40}$ Ibid.

${ }^{41}$ Simon Butt, "Regional Autonomy and the Proliferation of Perda in Indonesia: An Assessment of Bureaucratic and Judicial Review Mechanisms," Sydney Law Review 32,2 (2010): 177. For example, in January 2013, a MOHA spokesperson revealed that of the 1,878 bylaws invalidated by the Home Affairs Ministry, almost 1,800 of them concerned regional taxes and levies. The remaining twenty-nine dealt with third-party political donations, and twenty-two pertained to alcoholic beverage regulation. Of the 750 Perda under review at time of writing, 589 concerned regional taxes and levies, 19 concerned alcoholic beverages, and 71 concerned third-party political donations. See Parlina and Aritonang, "After Straddling Proposal, Ministry to Review Bylaws."

${ }^{42}$ Panduan praktis memahami perancangan peraturan daerah (Jakarta: Direktorat Jenderal Peraturan Perundang-undangan Departemen Hukum dan HAM bekerjasama dengan United National Development Programme; CAPPLER Project, 2008); "Banyak Perda Abaikan Kaidah Yang Berlaku," Hukumonline, March 16, 2012.
} 
to avoid revocation. This is often successful because there appear to be no formal sanctions for failure to submit many types of Perda to the central government. ${ }^{43}$ Another reason is that MOHA lacks resources to review the large number of regional laws it receives. Our research revealed that reviews are conducted by relatively small MOHA teams that meet only weekly and cannot allocate sufficient time to the task. ${ }^{44}$ Most post-enactment reviews are, therefore, not completed within the sixty-day time limit imposed by Law No. 32 of 2004. As mentioned, after sixty days, the Perda therefore comes into force automatically without review. ${ }^{45}$ The result, we suspect, is that many bylaws that contradict national statutes and regulations-including those national laws that impose human rights standards, such as the Constitution-remain on the books.

While focus on revenue-raising Perda might be politically motivated, it is supported and facilitated by the legal framework. Notably, unlike other Perda, revenue-raising Perda are subject to both pre- and post-enactment review. Moreover, prior to the enactment of Law 28 of 2009 on Regional Taxes and User Charges, there were no time limitations for review of revenue-raising Perda, and they could be revoked by the MOHA rather than the president if local governments issued them without adhering to the central government's directions during pre-enactment review. ${ }^{46}$ This made the process for reviewing Perda that imposed taxes and user charges much easier than for other types of Perda. While Law 28 of 2009 introduced a mechanism and time limit for revenue-raising Perda to be reviewed and annulled post-enactment by the president, it did not explicitly repeal the MOHA's power to revoke at any time revenue-raising Perda that did not adhere to central government direction during pre-enactment review. Whether this MOHA power was implicitly repealed or not has not yet arisen for decision by the Supreme Court, as the MOHA has not, to our knowledge, formally revoked any revenue-raising Perda since Law No. 28 of 2009 took effect.

\section{The Politics of Bureaucratic Review}

Despite the very significant problems with bureaucratic review that we have outlined, the central government appears to be under very little pressure to reform the process. In 1999, when Indonesia's framework for regional autonomy was being devised, there were undoubtedly good policy reasons for the national government to supervise regional governments. For the thirty-three years of Suharto's reign, regional governments had, for the most part, done little more than implement national government policy in the regions. Most had no experience in making policy or law.

\footnotetext{
${ }^{43}$ Interview with Janurudin from Department of Home Affairs, conducted by M. Nur Sholikin and Siti Maryam Rodja, January 19, 2011. By contrast, the central government can impose financial penalties upon regional governments that fail to submit their tax and user charge bylaws for review within the time specified (Law No. 28 of 2009 Art 159(1)).

${ }^{44}$ See also David Ray, "Decentralization, Regulatory Reform, and the Business Climate," in Decentralization, Regulatory Reform, and the Business Climate (Jakarta: Partnership for Economic Growth, 2003), p. 18.

${ }^{45}$ We note that any ministry unit - in Indonesia or beyond-would likely find meeting the law's tight time frames difficult, given the complexity of the task, the required knowledge of areas of national law with which bylaws must comply, the need to coordinate with other ministries and experts, and the vast numbers of regional laws submitted for assessment.

${ }^{46} 2004$ Regional Governance Law Articles 185(5), 186(5), 189.
} 
As time passes and local lawmakers become more experienced, however, debate intensifies about whether bylaws should be reviewable by the central government, or by any body other than the local lawmaker itself. Different opinions stem from the variety of views held in Indonesia about what decentralization means and how it should work. We have identified two main strains of opinion emerging out of the field research conducted for this paper, including interviews and a roundtable with officials from the Home Affairs Ministry, the Law and Human Rights Ministry, the National Development Planning Agency (BAPPENAS, Badan Perencanaan Pembangunan Nasional), local governments, and the Supreme Court, as well as parliamentarians, non-government organizations, and academics. ${ }^{47}$

The first group-which we call the "protectionists"-primarily comprises civilsociety organizations, community groups, citizens, and reformists, but also some central government officials. The thrust of this strain is that Indonesian citizens need protection from local governments, some of which are incompetent, predatory, or both. For protectionists, existing executive and even the judicial review mechanisms (discussed below) are woefully inadequate and must, therefore, be overhauled or replaced. The central government-despite facing similar criticisms and its own challenges-has more human and financial resources at its disposal and thus should be responsible for providing that protection.

Protectionists point out that many of these bylaws, including the so-called Perda Syariah, appear to threaten universal human rights that are also provided for under Indonesia's Constitution and other domestic laws. ${ }^{48}$ However, local laws have certainly been criticized not only for their potential to breach human rights. Important public services, environmental protection, natural resources, international obligations, and Indonesia's legal order are all at stake. ${ }^{49}$ Although there are undoubtedly exceptions, many bylaws have been criticized for being unworkably unclear, meeting no apparent regulatory need, and for not being preceded by any public consultation. ${ }^{50} \mathrm{~A}$ common complaint is that many bylaws seek to do little more than exact over-exploitative taxes and user charges (retribusi), for which the receiving local government provides few

${ }^{47}$ Fieldwork for this research was funded by AusAID. In January 2011, interviews were conducted with various government officials, including from the Supreme Court, MOHA, the finance ministry, and local parliamentarians. Interviews were also held with academics, practitioners, and non-government organizations. In March 2011, a roundtable discussion on Perda review mechanisms organized as part of this research was attended by a number of participants from government institutions involved in the review of Perda. These included the MOHA Legal Bureau, Perda Drafting Facilitation Director of the Department of Law and Human Rights, Law Analysis Directorate of BAPPENAS, the national women's commission, Committee Supervising the Implementation of Regional Autonomy (Komite Pemantauan Pelaksanaan Otonomi Daerah), Association of Indonesian City Governments, and the National Legal Aid Institute of Jakarta (Lembaga Bantuan Hukum Jakarta).

${ }^{48}$ See also "Under the Syariah Umbrella," Tempo, September 6, 2011; "Perda Bermasalah, Buah Otonomi Kebablasan," Hukumonline, October 27, 2007; Nurun Nisa, Gamal Ferdhi, and Nurul Huda, "Bersama Menolak Perda Diskriminatif," Nawala: The Wahid Institute, June 2007; "Hanya Lima Persen Perda Berperspektif HAM"; and "3200 Perda Bertentangan Dengan HAM."

${ }^{49}$ Butt, "Regional Autonomy and the Proliferation of Perda in Indonesia"; Christopher M. Barr and Center for International Forestry Research, Decentralization of Forest Administration in Indonesia: Implications for Forest Sustainability, Economic Development, and Community Livelihoods (Sindang Barang, Bogor: Center for International Forestry Research, 2006).

${ }^{50}$ See also Ray, "Decentralization, Regulatory Reform, and the Business Climate." 
benefits or services, if any. ${ }^{51}$ For example, the Indonesian Chamber of Industry (Kamar Dagang dan Industri Indonesia, KADIN) commonly complains that, quite apart from their excessive cost and number, many of these taxes appear to duplicate other taxes issued by another tier of government, leading to confusion as to which of them are legally payable. The result is said to be a "high cost economy" that damages Indonesia's investment climate. ${ }^{52}$

The second group-the "autonomists" - primarily comprises local governments, although it also encompasses many members of the national executive, legislature, and judiciary interviewed as part of this research. Autonomists tend to emphasize that the genuine intent of decentralization was, in fact, to hand over significant power and responsibility to local governments. ${ }^{53}$ For them, decentralization is about giving real autonomy to local governments and, presuming that local elections are free and fair, leaving it to citizens to remove non-performing local governments. According to autonomists, how local governments exercise their autonomy is, for better or for worse, a matter for them and their constituents to decide unless it intrudes upon legitimate central government interests. If bylaws are to be reviewed at all, then, they should be reviewed by an independent body, such as a court, not by the national government. Autonomists commonly appeal to democratic principles to justify their position, arguing that because local legislators are elected, they should be able to enact any law that they wish. However, the main weakness of this position is that the very laws granting power to local governments to enact Perda in the first place do not give them carte blanche. The first regional autonomy statute, enacted in 1999, made this clear, delineating the relative jurisdiction of the various tiers of government, as have subsequent laws, including the Constitution, as mentioned above. In other words, there are "rules of the game," even though, as we shall see, both their content and operation are not always clear.

\footnotetext{
${ }^{51}$ According to one estimate, for the first six years of decentralization, local governments established around one thousand new taxes and user charges (retribusi) per year. See Blane D. Lewis and Bambang Suharnoko Sjahir, "Local Tax Effects on the Business Climate," in Rural Investment Climate in Indonesia, ed. Neil McCulloch (Singapore: SEAS, 2009), pp. 224-245, esp. 224, 231.

52 See also Pratikno, "Exercising Freedom: Local Autonomy and Democracy in Indonesia, 1999-2001," in Regionalism in Post-Suharto Indonesia, ed. Priyambudi Sulistiyanto, Maribeth Erb, and Caroline Faucher (New York, NY: RoutledgeCurzon, 2005), p. 21; Пlyas Saad, "Implementasi Otonomi Daerah Sudah Mengarah Pada Penciptaan Distorsi Dan High Cost Economy," in Decentralization, Regulatory Reform, and the Business Climate (Jakarta: Partnership for Economic Growth, 2003); Bambang Brodjonegoro, "Three Years of Fiscal Decentralization in Indonesia: Its Impacts on Regional Economic Development and Fiscal Sustainability," paper presented at the Fiscal Decentralization in Asia Revisited conference, Hitotsubashi University, 2004; UNDP, "Enhancing Communications, Advocacy and Public Participation Capacity for Legal Reforms (CAPPLER) PHASE I"' (United Nations Development Programme, 2008); Agus Maryono, "Thousands of Bylaws Halt Investment: BKPM," Jakarta Post, October 23, 2009; "Indonesia Failing to Cash in on Mineral Surge: Analysts," Antara, November 12, 2007; and OECD, OECD Investment Policy Reviews (Paris: Organisation for Economic Co-operation and Development, 2010), p. 21.

${ }^{53}$ See also Donald L. Horowitz, Constitutional Change and Democracy in Indonesia (New York, NY: Cambridge University Press, 2013); and Harold Crouch, Political Reform in Indonesia after Soeharto (Singapore: ISEAS, 2010).
} 


\section{Part II: The Review Jurisdiction of the Supreme Court}

In practical terms, there are two avenues by which the validity of a Perda can be challenged before the Supreme Court. The first is the 2004 Regional Governance Law, under which regional governments whose bylaws have been revoked by the central government can challenge such revocations. ${ }^{54}$ In this category of cases, the Supreme Court will usually review the lawfulness of the revoked bylaw in order to determine whether it was validly revoked. In some cases, the issue before the Court will be whether the central government adhered to the lawful procedures in revoking the bylaw. In most cases, however, the main issue for the Court will be whether the revoked bylaw was, in fact, contrary to a higher law or the public interest as claimed by the central government.

The second channel is its broader general judicial review power. ${ }^{55}$ This power allows the Court to "check" both whether the substance of a law is valid (the so-called hak uji materiil) and whether all relevant procedures for the enactment of the law were adhered to (hak uji formil). ${ }^{56}$ Though the Supreme Court Law gives the Court power to review both aspects, the Supreme Court itself has only established procedures for hearing the first type- "hak uji materiil" —and, as a result, the Court has not yet heard any cases of the second type.

Applications for judicial review (hak uji materiil) can be made directly to the Supreme Court, or via the applicant's local district court (pengadilan negeri). ${ }^{57}$ To have legal standing, an applicant must show that his or her rights or interests have been adversely affected by the enactment of the legal instrument. ${ }^{58}$ Applicants may be individual Indonesian citizens, customary community groups (kesatuan masyarakat hukum adat), as well as public or private legal entities. ${ }^{59}$ This avenue of review, therefore, is available to local governments, businesses, and citizens alike. Laws struck down by the Supreme Court will no longer be legally binding. ${ }^{60}$ These Supreme Court decisions are not subject to appeal. ${ }^{61}$

\footnotetext{
${ }^{54}$ Article 145(5) of Law No 32 of 2004 provides that regional governments can challenge in the Supreme Court the post-enactment revocation by Presidential Regulation of their Perda. Government Regulation No. 79 of 2005 Article 41 provides that regional governments can challenge in the Supreme Court the postenactment revocation by MOHA Regulations or Governor's Regulations of their tax or user charge Perda.

${ }^{55}$ Whether the first avenue of review stands alone or is a subcategory of the Supreme Court's general judicial review power has provoked some academic disagreement, but has not yet, to our knowledge, attracted judicial consideration: "Berangkat Dari Pembatalan Perda Privatisasi Rumah Sakit: Problem Hukum Pengujian Perda (1)," Hukumonline, June 22, 2006.

${ }^{56}$ Law No. 14 of 1985 on the Supreme Court Article 31(2). This is confirmed both in Law No. 4 of 2004 on the Judiciary Article 11(2)(b) and Law No. 14 of 1985 on the Supreme Court Article 31(1).

${ }^{57}$ Law No. 4 of 2004 on Judicial Power Article 11(3); Law No. 14 of 1985 on the Supreme Court Article 31(3).

${ }^{58}$ Law No. 14 of 1985 Article 31A(2).

${ }^{59}$ Ibid.

${ }^{60}$ Law No. 14 of 1985 Article 31(4).

${ }^{61}$ Supreme Court Regulation No. 1 of 2011 on Material Review Article 9.
} 


\section{The "Rules of the Game": The Hierarchy of Laws}

As for the higher-level law ground for invalidity, the starting place is Indonesia's "hierarchy of laws," contained in Article 7(1) of Law No. 12 of 2011 on Law-Making ("the Lawmaking Law"), which is as follows:

The Constitution;

$\mathrm{MPR}^{62}$ Decisions;

Statutes/Interim Emergency Laws;

Government Regulations;

Presidential Regulations;

Provincial Perda; and

District and city Perda.

The hierarchy lists various types of laws in descending order of their legal authority vis-à-vis the other types of laws on the list. For example, a government regulation must not contradict a statute enacted by Indonesia's parliament or the Constitution, which occupies prime position on the hierarchy. However, a government regulation will prevail over a presidential regulation in the event of any inconsistency.

At the bottom of the list, Perda issued by provincial, city, and district governments are in a weak position vis-à-vis the other laws on the hierarchy: when enacted, those bylaws must not contradict those higher-level national laws, and after enactment, those bylaws are susceptible to repeal by higher-level national laws. District and city Perda are particularly weak given that they must contradict neither those higher-level national laws nor provincial Perda. ${ }^{63}$

At first glance, the hierarchy might appear to provide order to the Indonesian legal system by clearly delineating the authority of various types of laws and the institutions that make them. Thus, if a Perda contradicts a statute, that Perda will be formally invalid to the extent of any inconsistency. Pointing to the hierarchy, some scholars have argued that Perda Syariah are invalid because they deal with religion-a matter exclusively reserved for the central government by statute, ${ }^{04}$ a law higher than Perda in the hierarchy.

However, the hierarchy is incomplete, and its practical application is often highly problematic. Article 8 of the Lawmaking Law provides that types of laws outside the hierarchy have legal effect insofar as their enactment is pursuant to a law listed on the hierarchy. It states:

(1) Types of laws other than those referred to in Article 7(1) include regulations stipulated by the People's Consultative Assembly, the People's Representative Council, the Regional Representative Council, the Supreme Court, the Constitutional Court, the National Audit Agency, the Judicial

\footnotetext{
${ }^{62}$ Majelis Permusyawaratan Rakyat, the People's Consultative Assembly.

${ }^{63}$ Law No. 12 of 2011 Article 7(2).

${ }^{64} 2004$ Regional Governance Law Article 10(3).
} 
Commission, Bank Indonesia, Ministers, or equivalent agencies, institutions or commissions established by statute or by the government as required by statute, Provincial People's Representative Councils, Governors, County/City People's Representative Councils, the Mayor/County Heads, Village Heads or equivalent.

(2) The types of laws referred to in Article 8(1) are recognized and have binding legal force to the extent that they are required by higher level laws or on the basis of authority.

In practice, Article 8 significantly undermines the order that the hierarchy purports to bring to the legal system. Many types of laws very frequently employed in Indonesia are not mentioned on the list contained in Article 7(1), so even though they are given legal force by virtue of Article $8(2)$, their authority vis-à-vis other laws is therefore unclear.

Take, for example, a statute that authorizes the central Bank of Indonesia to issue regulations on monetary policy, and the Finance Minister to regulate the finance sector. If these regulations conflict with each other and a regional tax Perda, which of the three regulations takes precedence over the other two? As for the Bank of Indonesia Regulation and the Finance Minister Regulation, they are both authorized by the same statute, and the hierarchy provides no mechanisms to resolve the inconsistency between them.

The status of Perda vis-à-zis Ministerial Regulations and Decisions is a highly vexed question. On the one hand, some argue that ministerial regulations should be treated as sitting between presidential regulations and provincial regulations because ministers are senior national officials appointed by the president. The National Legal Development Agency (Badan Pembinaan Hukum Nasional, BPHN) supports this view, pointing to Article 17 of the Constitution, which provides that ministers are to help the president administer government on a national scale. ${ }^{65}$ The Agency concludes:

The scope of a Ministerial Regulation's force is national, meaning it takes effect throughout the whole of the unitary state of the Republic of Indonesia's territory ... [I]t can be concluded that Ministerial Regulations are above Perda: a Perda's effect is limited to its respective region, whereas a Ministerial Regulation's effect is national. Because a Ministerial Regulation is higher than a Perda, a Perda cannot be inconsistent with a Ministerial Regulation. ${ }^{66}$

In our view, the agency's arguments are unconvincing. Its interpretation uncritically equates broader geographic force with a status "higher" on the hierarchy. The Constitution recognizes the role in government of both ministers and regional governments. Both are given law-making powers by statute, and the laws of both should be presumed to have full effect within their respective areas of jurisdiction, unless provided otherwise by law. National statutes commonly delegate power to ministers to issue regulations and decisions, and to local governments to issue Perda. If

\footnotetext{
${ }^{65}$ Noor M. Aziz, Laporan Akhir Pengkajian Hukum Tentang Eksistensi Peraturan Perundang-Undangan Di Luar Hierarki Berdasarkan UU No. 10 Tahun 2004 Tentang Pembentukan Peraturan Perundang-Undangan (Jakarta: Badan Pembinaan Hukum Nasional Departemen Kehakiman, 2010), pp. 51-55.

${ }^{66}$ Ibid. at p. 54.
} 
these instruments are both issued in response to a statutory delegation of power, why should one trump the other? It might, indeed, be desirable for ministers to be given the power to override Perda, but this needs to be expressly stipulated in the Constitution or in statute. Since the Constitution recognizes the "widest possible" autonomy, regional governments and their citizens have a legitimate expectation of autonomy, and any decision to limit that autonomy (by, for instance, giving ministers the power to trump Perda) should be taken by parliament.

In 2001, the Justice and Human Rights Minister issued a Circular Letter that sought to resolve this ambiguity. ${ }^{67}$ The Circular declared that Ministerial Regulations sit below Presidential Regulations and above Perda on the hierarchy. ${ }^{68}$ However, somewhat ironically, Circular Letters themselves have a notoriously ambiguous legal status and certainly cannot "override" or add to the hierarchy outlined in the Lawmaking Law. Moreover, if, contrary to the minister's view, Perda in fact do trump Ministerial Regulations, the minister would not have the power to elevate the authority of his own regulations by issuing a Circular or any other instrument.

With a view to removing ambiguity, the National Legal Development Agency recommended that the Lawmaking Law be amended as follows:

Regulations issued by state institutions that are established by the Constitution, such as the Finance Auditing Agency, Bank Indonesia, General Election Commission, Supreme Court, Constitutional Court, and the Judicial Commission, should be expressly mentioned on the hierarchy and positioned alongside Presidential Regulations;

Ministerial Regulations should be placed on the hierarchy below Presidential Regulations and above Provincial Perda;

Governor Regulations should be placed on the hierarchy below Provincial Perda and above District and City Perda; and

Mayor and District Head Regulations should be placed on the hierarchy below city and district Perda. ${ }^{69}$

However, the national parliament appeared to ignore these recommendations when it revised the hierarchy of laws in 2011, which, as demonstrated above, does not mention most of these laws.

Adding to the confusion arising from the hierarchy is the unclear status of a lowerlevel law after the higher-level law upon which it relies for its authority is amended, repealed, or replaced. For example, when a statute is replaced, the new statute customarily stipulates a time within which new subordinate legislation, or regulations, must be enacted. These time frames are, however, routinely flouted in Indonesia. To avoid a legal vacuum, new statutes typically provide that lower-level laws made under the old statute remain in force "to the extent [that they are] not inconsistent with" the new statute. Thus, to determine whether a lower-level law issued under a replaced or

\footnotetext{
${ }^{67}$ Circular Letter dated February 23, 2001, cited in Maria Farida Indrati, Ilmu Perundang-undangan: Jenis, Fungsi, dan materi Muatan (Yogyakarta: Kanisius, 2007), p. 94.

${ }^{6 s}$ Ibid.

${ }^{69}$ Aziz, Laporan Akhir Pengkajian Hukum, p. 73.
} 
amended statute remains formally valid, governments, business, and citizens alike must often engage in the imprecise task of assessing whether that lower law is consistent with the current statute. However, the Indonesian Supreme Court has, as discussed below, provided little guidance on how to assess whether laws are consistent or if they conflict.

Ultimately, however, the confusion arising from the hierarchy is moot if the hierarchy itself is unenforceable. Unfortunately, most types of laws on the hierarchy appear not to be enforceable or reviewable as against many of the others. This is because, as Indonesian law currently stands, there are wide gaps in the Supreme Court's general judicial review jurisdiction, as we discuss in Part III. (Even though this is currently a significant impediment, in Part IV we suggest legal avenues by which it might be overcome.) Additionally, as discussed, the Indonesian Supreme Court appears to shrink from even those conflicts that it has power to review.

\section{Part III: Supreme Court's Exercise of Its Judicial Review Powers}

For Indonesia's Supreme Court, exercising judicial review powers is a relatively new endeavor. Even though the Court has had the formal power to review lower-level laws from the early $1970 \mathrm{~s}^{711}$ the Court all but refused to exercise it until after Suharto's resignation in $1998 .^{71}$ In addition, the judicial review powers that the Court did possess were strictly circumscribed: even if the Court had found a law to be invalid, it lacked formal authority to strike down that law. Only the government official or institution that issued the law could do this. ${ }^{72}$ Thus, the Court's powers of review were merely "declaratory." ${ }^{73}$ Moreover, the Court could only consider the validity of a law if the issue arose on cassation (appeal). ${ }^{74}$ Both this formal limitation of the Supreme Court's powers and the Court's reluctance to exercise those powers were consistent with and exacerbated by the general judicial subservience to government during Suharto's reign. As mentioned in the introduction, during this period the courts were heavily dependent on government, which was largely able to dictate to judges the decisions it wished them to reach. ${ }^{75}$

However, in 2004, administrative control over the judiciary was transferred to the Supreme Court under the so-called satu atap (one roof) reforms. The Court's judicial review power was strengthened to provide that laws declared invalid by the Court do not have legal effect ${ }^{76}$ and to allow challenges to the validity of a law to be made

\footnotetext{
${ }^{70}$ Law No. 14 of 1970 on Judicial Power Article 26(1).

${ }^{71}$ In the 1960s, however, the Supreme Court formally decided not to apply several provisions of the Civil Code that were deemed contrary to the 1945 Constitution. See Supreme Court Circular Letter No. 3 of 1963 , September 5, 1963; Daniel Lev, "The Lady and the Banyan Tree: Civil-law Change in Indonesia," The American Journal of Comparative Law 14,2 (1965): 282-83; Sudargo Gautama and Robert Hornick, An Introduction to Indonesian Law: Unity in Diversity, rev. ed. (Bandung: Alumni Press, 1983), p. 185; and Z Ansori Ahmad, Sejarah Dan Kedudukan BW Di Indonesia. (Jakarta: Rajawali, 1986).

${ }^{72}$ Law No. 14 of 1970 on Judicial Power Article 26(3); Law No. 14 of 1985 Article 31(4).

${ }^{73}$ Muhammad Ridhwan Indra, Kedudukan lembaga-lembaga negara dan hak menguji menurut undang-undang dasar 1945 (Jakarta: Sinar Grafika, 1987), p. 142.

${ }^{74}$ Law No. 14 of 1970 Article 26(2); Law No. 14 of 1985 Article 31(3).

${ }^{75}$ Lev, "Judicial Authority and the Struggle for an Indonesian Rechtsstaat."

${ }^{76}$ Law No. 14 of 1985 Article 31(2) as amended by Law No. 5 of 2004.
} 
directly to the Court, rather than only incidentally through an appeal. ${ }^{77}$ These reforms, combined with the new rules allowing applicants to bring judicial review cases directly to the Court, appear to have spurred the lodgment of a significant number of Supreme Court judicial review applications. According to Court statistics, it heard around two hundred judicial review cases in $2004-09,{ }^{78}$ sixty-one cases in $2010,{ }^{79}$ fifty in 2011 , and fifty-six in 2012. ${ }^{(1)}$ In 2011, twelve of these were reviews of bylaws; ${ }^{81}$ and in 2012, fifteen were such reviews. ${ }^{82}$

The Court also appears no longer to feel constrained by the government in the exercise of its judicial powers. As we shall see, the Court has been willing to strike down laws issued by the government and even the president, something it would not have done during Suharto's reign. In some cases, ${ }^{83}$ the Court has even appeared to adopt creative judicial reasoning to overcome significant legal obstacles in order to invalidate regional government regulations. However, as we demonstrate in the following sections, the exercise of the Supreme Court's judicial review powers remain problematic for other reasons, including an incomplete legal infrastructure for resolving disputes. The problem is exacerbated by lack of consistent, principled, and transparent judicial reasoning.

\section{Overview of Cases Studied}

As mentioned, we base our analysis upon an examination of the forty-six judgments in judicial review cases available on the Supreme Court's website. Twelve of these were challenges to regional legislative decisions (none of which was successful), six to laws issued by governors and district heads (three were successful), and thirteen were challenges brought by local governments against central government decisions to invalidate their legislation (two were successful). Sixteen were challenges to regional legislation. Of these, five were successful, of which two sought to establish fees for services (retribusi), two related to prohibitions on alcohol, and one related to the incorporation of hospitals.

The single most common reason the Court employed to reject an application was that it had been filed out of time. Until recently, the Supreme Court had, by Supreme Court Regulation, ${ }^{84}$ imposed upon applicants a 180 -day time limit to lodge an application for judicial review of a law, running from the date that the law was

\footnotetext{
${ }^{77}$ Law No 14 of 1985 Article 31(3) as amended by Law No. 5 of 2004.

${ }^{78}$ Parsons and Mietzner, "Sharia By-laws in Indonesia," p. 198.

${ }^{79}$ Mahkamah Agung, Laporan Tahunan 2010 (Jakarta: Mahkamah Agung, 2011), p. 75.

${ }^{80}$ Mahkamah Agung, Laporan Tahunan 2012 (Jakarta: Mahkamah Agung, 2013).

${ }^{81}$ Six were regional legislation, four were governor regulations, two were regent regulations, and one was a governor's decision: Mahkamah Agung, Laporan Tahunan 2011 (Jakarta: Mahkamah Agung, 2012 ), p. 14.

${ }^{82}$ Of these, ten were regional legislation, two were regent regulations, two were laws issued by governors, and one was a mayoral regulation: Mahkamah Agung, Laporan Tahunan 2012.

${ }^{83}$ See, for example, the "Prohibition Perda" cases discussed below.

${ }^{84}$ Supreme Court Regulation No. 1 of 2004 Article 2(4) and before that in Supreme Court Regulation No. 1 of 1999 Article 5(4)
} 
enacted. ${ }^{85}$ The 180-day time period has now been abolished by Supreme Court Regulation. ${ }^{86}$

The next most common reason for the Court to reject an application was that the instrument challenged was administrative in nature, not legislative, an issue to which we return below. Two applications were rejected on the ground that the applicants did not have legal standing.

\section{Procedural Weaknesses}

Like bureaucratic review, judicial review, as currently exercised by the Supreme Court, has many flaws. As we shall see, many of them reflect broader practices and procedures that the Supreme Court employs in other types of cases, and some of the systemic problems it faces. In Part IV we suggest how some of these shortcomings might be overcome.

Our research revealed several procedural shortcomings, three of which we discuss here. The first is lack of transparency in case management and administration. Once applicants have submitted their judicial review applications, they are given no information about the progress of their case. The Court often posts the outcome of its cases on the Supreme Court's website without notifying the applicant and before the applicant receives a copy of the judgment. ${ }^{87}$ Alarmingly, the Court has occasionallyincluding in the infamous Tangerang prostitution Perda case, discussed belowannounced decisions by press release without making any written judgement available, even to the parties to the dispute.

In 2007, the Supreme Court Chief Justice issued a decree ${ }^{88}$ that required all courts, including itself, to provide public access to various court documents, including judicial decisions. To be sure, this is an onerous obligation, and the Court has, on the whole, performed it well: there were, in mid-2003, over 40,000 Supreme Court decisions publicly available on the Court's website, along with many thousands of decisions issued by other Indonesian courts. However, the number of decisions now available

\footnotetext{
${ }^{85}$ Our research indicates that the Supreme Court had been inconsistent in the way it applied the 180-day time limit. For instance, to determine whether the application was brought "in time," the Court would sometimes use the date on the application, but in other cases would use the date the application was officially registered with the Supreme Court. The difference was often significant, particularly for applicants who lodged their challenge with the local district court (pengadilan negeri) and discovered that their applications were registered with the Supreme Court much later. The Court would, on occasion, allow "late" applications to be heard (e.g., Decision No. 20.P/HUM/2002), but rejected others with no explanation (e.g., Decision No. 05.G/HUM/2001). Most alarming, however, were cases in which the Court dismissed applications for being out of time even when they were, in fact, registered within 180 days of the enactment of the challenged law (e.g., Decision Nos. 08.P/HUM/ 2004 and 09.P/HUM/2004). Whether deliberate or in error, the Court's decisions are final and not subject to appeal.

${ }^{86}$ No. 1 of 2011.

${ }^{87}$ In some cases, the Court took several months to inform the applicant of the decision and to send the decision to the applicant: Simon Butt and Nicholas Parsons, "Analytical Paper: Perda Review Mechanisms," report prepared for AusAID, on file with authors, 2011. These time frames for making decisions are, in fact, not particularly bad by world standards, though, of course it is difficult to understand why informing the applicant of the decision and sending a copy takes so long.

${ }^{88}$ 144/KMA/VIII/ 2007.
} 
online constitutes only a fraction of the Court's decided cases-between them, the Supreme Court's fifty or so judges decide well over ten thousand cases per annum. ${ }^{89}$

The second procedural shortcoming relates to the way arguments are presented to and considered by the Court. Like many courts of final appeal in civil law countries, ${ }^{90}$ the Indonesian Supreme Court usually does not provide an opportunity for the parties to present oral argument or to respond directly to the submissions of the other side. After the parties lodge their written submissions to the Court, the judges allocated to the case then meet to discuss the case and come to a decision. ${ }^{91}$ Virtually all Supreme Court cases-whether civil, criminal, or administrative-are decided using this process.

Third, the Court has adopted practices that allow a bylaw, no matter how egregiously it violates the rights of citizens, to be applied while the Court is deciding upon its validity. The Supreme Court takes, on average, around three years to decide each bylaw review case studied, with the shortest taking one month ${ }^{92}$ and the longest eight years. ${ }^{93}$ However, the Court does not issue interim or interlocutory injunctions in bylaw review-or any judicial review-cases. Suspending the application of the bylaw would prevent citizens from continuing to labor under an oppressive bylaw while the Supreme Court examines the parties' submissions.

Further, if found to be invalid, bylaws are held to be void from the date of the relevant Supreme Court decision, not ab initio (from the time of enactment). The refusal to issue injunctions and to invalidate $a b$ initio significantly diminishes the utility for citizens of bringing a claim and, ultimately, undermines the authority of the Court.

\section{Reviewability of Perda Revocations}

The particular national legal instrument needed to revoke Perda has caused much confusion. Also unclear is whether revocation by another legal instrument will be effective. Prior to the 2004 Regional Governance Law's enactment, Perda were revoked by the MOHA on behalf of the central government. ${ }^{94}$ The 2004 Regional Governance Law changed this, identifying Presidential Regulations as the instrument to revoke

\footnotetext{
${ }^{89}$ In 2007, the Court cleared 10,554 cases; in 2008, 9,351; in 2009, 14,483; in 2010, 14,662; in 2011, 15,223, and in 2012, 12,520: Mahkamah Agung, Laporan Tahunan 2012.

${ }^{90}$ See, generally, John Merryman, The Civil Law Tradition: An Introduction to the Legal Systems of Western Europe and Latin America. (Stanford, CA: Stanford University Press, 1984).

${ }^{91}$ Pedoman Pelaksanaan Tugas Dan Administrasi Pada Mahkamah Agung (Jakarta: Mahkamah Agung, 2006), pp. 131-33.

${ }^{92}$ Supreme Court Decision No. 03.P/HUM/2009.

${ }^{93}$ Supreme Court Decision No. 03.G/HUM/2000. In several of the cases in which the Court was asked to review regulations about district head elections, the Court issued its decisions after the term of the official elected under the disputed rules had already expired. See Supreme Court Decision Nos. 02.G/HUM/2000; 03.G/HUM/2000; 04.P/HUM/2000;05.P/HUM/2000; 04.P/HUM/ 2002; 19.P/HUM/ 2002; 15.P/HUM/2003; 02.P/HUM/2004.

${ }^{94}$ Law No. 22 of 1999 Art 114(1) stipulated simply that Perda were to be revoked by the central government. Government Regulation No. 20 of 2001 Article 10(1) specified that the MOHA was to issue these revocations in the name of the president. Article 10(2) of the same regulation gave governors as central government representatives the power to revoke city and district level bylaws. Article 17(2) of Government Regulation No. 66 of 2001 on User Charges gave the MOHA the same power with respect to Perda on user charges.
} 
Perda ${ }^{95}$ except for revenue raising Perda requiring pre-enactment review. ${ }^{96}$ Even so, almost all Perda revoked to date have been by MOHA Decision. Only one Perda has been invalidated by Presidential Regulation. ${ }^{47}$ It is arguable, then, that the MOHA lacks statutory authority to revoke most Perda, and that, therefore, its decisions purporting to revoke Perda are themselves invalid.

Perversely, however, these MOHA Decisions may be immune from reviewjudicial or otherwise. As mentioned, the Supreme Court has special jurisdiction under Article 145(5) of the 2004 Regional Governance Law to review only the validity of Presidential Regulations that purport to revoke Perda, not MOHA Decisions. Further, it arguably has no power under its general review jurisdiction to review revocations by MOHA. Its general jurisdiction extends only to legal instruments that are "regulatory" (mengatur) - that is, which contain an abstract "legal norm" that binds the general public (mengikat umum). ${ }^{98}$ However, MOHA Decisions-or, indeed, any decision that revokes a regional law-are most likely properly characterized as administrative decisions (keputusan tata usaha negara), which are "individual, concrete, and final" because they are, in effect, orders that specific Perda be revoked within a particular time frame. If the MOHA Decisions revoking Perda were to be characterized as administrative decisions, the Supreme Court could not review them using its general judicial review jurisdiction. Rather, the dispute would be about an administrative

\footnotetext{
${ }^{95}$ Article 145(2) stipulates that the central government is to invalidate Perda on specified grounds, and Article 145(3) specifies that invalidations under Article 145(2) are to be by Presidential Regulation

${ }^{96}$ Under Articles 185(5) and 189 of the 2004 Regional Governance Law, the MOHA has power to revoke provincial Perda at any time if enacted without adhering to pre-enactment review procedures established under the law. Similarly, Articles 186(5) and 189 gave governors the power to revoke city and district level Perda for ignoring pre-enactment review procedures. These provisions might explain the high number of tax and user-charge Perda revoked by the MOHA. The enactment of Law No. 28 of 2009 on Regional Taxes and User Charges on September 15, 2009, adds further complexity. Law 28 of 2009, which deals specifically with the review of regional tax and user charge Perda, does not provide any scope for revocation by the MOHA. It instead stipulates that revocation is to be by Presidential Regulation based on a recommendation from the MOHA (Articles 158(4), (5)). As this statute deals specifically with the postenactment review of Perda that are required to have also undergone pre-enactment review, but does not provide any power to the MOHA to revoke Perda directly, this Law has arguably effectively repealed Articles 185, 186m, and 189 of the 2004 Regional Governance Law to the extent they applied to regional tax or user-charge Perda. However, it appears that the MOHA does not share this view. MOHA Regulation No. 53 of 2011 provides, in Articles 65(3) and 71(3), the same scope for MOHA to revoke Perda as under Law No. 32 of 2004. Art 70(3) provides the same power for provincial governors. This might be consistent with the view that Law No. 28 of 2009 did not intend to repeal implicitly those provisions of Law No. 32 of 2004 . It might, however, simply be contrary to Law No. 28 of 2009 and, to that extent, formally invalid.

${ }_{97}$ On October 18, 2006, President Susilo Bambang Yudhoyono issued Presidential Regulation No. 87 of 2006 on the Invalidation of Articles 33(2)(n) and 34(8) of Aceh Qanun No. 7 of 2006 (the Second Amendment to Aceh Qanun No. 2 of 2004 on the election of governors/deputy governors, bupati/deputy bupati, and mayors/deputy mayors in the Province of Aceh). It was suggested during interviews conducted as part of this research that the president might be reluctant to exercise his review powers to invalidate Perda because, under Law No. 32 of 2004, Presidential Regulations can be subject to challenge in the Supreme Court. In other words, by issuing invalidations, the president makes himself vulnerable to having his regulations struck down in favor of local government laws. This, it was suggested, would damage his reputation. We have been unable to verify this claim.

98 See the Lawmaking Law Article 1(2); Supreme Court Regulation No. 1 of 2011 Article 1(2).

${ }^{99}$ Article 1(9) of Law 51 of 2009 amending Law 5 of 1986 on the Administrative Courts.
} 
decision, which falls within the jurisdiction of the state administrative courts (pengadilan tata usaha negara). ${ }^{100}$

The Supreme Court has been inconsistent in its decision making about whether MOHA Decisions revoking regional laws are "regulatory" or "administrative" and has not yet settled this and other fundamental jurisdictional questions, let alone openly discussed them in its judgments. This is unfortunate, because such inconsistency and indecision allows the Supreme Court to refuse to hear a judicial review application, sometimes unpredictably, without providing much explanation. On the one hand, in a 2002 decision, ${ }^{101}$ the Court found that a MOHA Decision revoking a decree issued by a regional parliament was an administrative instrument and, therefore, fell beyond the Court's review jurisdiction. ${ }^{112}$ Faced with such a decision, a regional government could theoretically institute proceedings in the State Administrative Court to review the MOHA Decision in question. However, by the time the litigants receive the Supreme Court's decision, the ninety-day time limit to file a case in the State Administrative Court-which runs from the date of the issue of the administrative decision ${ }^{103}$-would likely have elapsed. On the other hand, in other cases, the Court has categorized these MOHA Decisions as legislative instruments and proceeded to review them. ${ }^{104}$ In yet another case, ${ }^{105}$ the Court held that the impugned MOHA Decision was invalid because only the president had the power to revoke such a Perda, not the MOHA.

\section{Absence of Reasoning and Academic Doctrine}

Generally speaking, the Supreme Court's jurisprudence and reasoning in judicial review cases is simplistic and superficial. Its judgments are often terse and provide little in the way of reasoning that future judges can develop as jurisprudence or that applicants can use to make arguments in subsequent cases. In many Perda review cases, the Court has not, in its judgments, discussed the substance of the relevant bylaw, the arguments of the parties, or even whether the bylaw contradicts any higher laws. ${ }^{106}$ In other words, the Court has been reluctant to consider the "merits" of the case ${ }^{107}$ The Court has, in some cases, been content simply to declare that the Perda is regional in scope and within the jurisdiction of the relevant local government "on the basis of Regional Autonomy ... ${ }^{108}$ It appears that this or a similar approach was taken in the infamous Tangerang Perda case, which concerned a bylaw that sought to ban prostitution. The Perda was used to arrest for suspected prostitution a pregnant

\footnotetext{
${ }^{100}$ More specifically, provided that the law was not characterized as "legislative," the Supreme Court would refuse to review it. We note here that laws might be categorized as neither legislative nor administrative, in which case its review falls outside the Court's jurisdiction.

${ }^{101}$ Supreme Court Decision No .02.G/HUM/2004.

${ }^{102}$ Ibid. at 24 .

${ }^{103}$ State Administrative Court Law Article 55.

${ }^{104}$ Supreme Court Decision Nos. 08.P/HUM/2004, 09.P/HUM/2004, 20.P/HUM/2007, 03.P/HUM/2009.

105 Supreme Court Decision No. 17.P/HUM/2005.

${ }^{106}$ See, for example, Supreme Court Decision Nos. 03 G/HUM/2002, 06 P/HUM/2003, and $06 \mathrm{P} / \mathrm{HUM} / 2006$.

${ }^{107}$ Butt, "Regional Autonomy and the Proliferation of Perda in Indonesia," p. 187.

${ }^{10 s}$ Supreme Court Decision No. 03 G/HUM/2002.
} 
waitress while she was waiting for a bus home one night. At a press conference, a Supreme Court spokesperson announced that the Court had decided that the Perda was formally valid because it had been enacted using proper parliamentary procedures and that the Perda's subject matter was within the jurisdiction of the Tangerang city government. ${ }^{109}$

Further, the Supreme Court appears to ignore selectively some of the time limits that the 2004 Regional Governance Law imposes on local governments that submit their Perda for pre-enactment review. For example, in one case involving a regional budget, ${ }^{110}$ the Court held, in essence, that it would not interfere with a budget enacted by a regional government simply because "[Regional governments] have the authority to regulate their budgets in accordance with conditions in their regions." The Court did not even mention the pre-approval requirements for budget Perda, let alone consider whether this Perda had met them. ${ }^{111}$ In another case, ${ }^{112}$ the Supreme Court upheld the validity of a MOHA Decision issued in 2007 that sought to revoke a Perda of the District of Nias enacted in 2002. Nias argued the 2004 Regional Governance Law only authorized the president to invalidate Perda, not the MOHA. Moreover, Nias pointed out that, even though it had submitted the Perda for review within fifteen days of its enactment, the MOHA Decision had breached the time limits within which it could legally revoke the Perda. ${ }^{113}$ The Supreme Court did not address any of the arguments raised by Nias or even whether the Court had jurisdiction to review a MOHA Decision. Instead, it simply held that the Perda did, in fact, seek to impose a fee on an object of central government tax and, therefore, violated higher-level laws.

This lack of engagement with the parties' arguments and the substance of the relevant Perda, and the relative absence of court-led jurisprudence, is not an uncommon feature of the Court's decision making in other types of cases or of judicial decision making in some countries adhering to the civil law tradition. ${ }^{144}$ However, in civil law countries in the developed world, such as in continental Europe, this lack of explanatory reasoning is often compensated by a rich body of academic literature, referred to as "doctrine," or doktrin in the Indonesian context. This literature is often consulted by judges and influences their decisions, thereby giving leading academic works semi-authoritative status and prompting lawyers to rely heavily upon them when advising clients and presenting arguments. In short, leading civil law academic commentaries, including discussion and analysis of important decisions, provide some of the background and legal arguments that lawyers in common-law countries might

\footnotetext{
109 "MA Tolak Permohonan Uji Materiil Perda Pelacuran Tangerang," Hukumonline, April 16, 2007.

${ }^{110}$ Supreme Court Decision No. 24 P/HUM/ 2002.

${ }^{111}$ Butt, "Regional Autonomy and the Proliferation of Perda in Indonesia," p. 187.

${ }^{112}$ Supreme Court Decision No. 20.P/HUM/ 2007.

${ }^{113}$ Article 25A(3) Law No. 18 of 1997 as amended by Law No. 34 of 2000 on Regional Taxes and User Charges and Government Regulation No. 66 of 2001 Article 17(3) gave the central government one month to respond; and Article 145(3) of the 2004 Regional Governance Law and Article 38(1) of Government Regulation No. 79 of 2005 allocate sixty days.

${ }^{114}$ Mitchel Lasser, Judicial Deliberations: A Comparative Analysis of Judicial Transparency and Legitimacy (Oxford and New York, NY: Oxford University Press, 2004).
} 
expect to be contained in judicial decisions themselves. ${ }^{115}$ Yet in Indonesia doctrine is largely underdeveloped, primarily because legal academics are poorly paid and need additional work to make ends meet, leaving them little or no time for research and developing doctrine. ${ }^{110}$

We argue that there is a need for more academic discussion about judicial review that attempts to distill general principles and provides frameworks for judges to use when deciding cases. Only a handful of academic texts about judicial review in Indonesia are available ${ }_{r}^{117}$ many of which are historical and descriptive rather than analytical. In particular, the two criteria for executive and judicial review of Perdapublic interest and consistency with a higher level law-are desperately un- or underdeveloped and demand scholarly attention. As for the public interest ground, we have found no significant judicial or academic discussion or debate about the concept, despite extensive searching. Public interest has rarely been invoked as a ground for invalidation of Perda, and, to our knowledge, has never been used as the sole ground for invalidation. ${ }^{118}$ This is surprising because the concept is vague and highly elastic, giving it significant potential for use (and abuse) whenever the MOHA or Supreme Court review Perda.

As for the higher-law ground, even though Indonesian lawyers often proclaim the hierarchy of laws as though it were self-explanatory, nothing could be further from the truth, as discussed above. In particular, the degree to which laws must overlap to be "inconsistent" is, to our knowledge, entirely ignored by most Indonesian commentators. Many unanswered questions remain. For example, are laws inconsistent simply if they cover the same subject matter as each other, even if they are quite different in their details? (Given the "Prohibition" Perda case study discussed below and various interviews conducted as part of this research, it appears that senior judges and government officials take the view that such laws would be inconsistent.) Is a Perda inconsistent with a higher-level law if it simply adds certain requirements or preconditions to that higher-level law? Or, rather, is this both expected and necessary when those higher-level laws are cast in very general terms, leaving detail to be fleshed out by local government representatives in recognition that they are best placed to "fit" rules to local conditions? In other jurisdictions, quite complex bodies of law and jurisprudence have been developed to help assess whether laws are, in fact, inconsistent.

\footnotetext{
${ }_{115}$ Mitchel Lasser, Anticipating Three Models of Judicial Control, Debate, and Legitimacy: The European Court of Justice, the Cour de Cassation, and the United States Supreme Court (New York, NY: New York University School of Law, 2003).

${ }^{116}$ Gary Bell, "The Importance of Private Law Doctrine in Indonesia," in Indonesia: Law and Society, ed. Tim Lindsey, 2nd ed. (Annandale, NSW: Federation Press, 2008); Simon Butt, "Judicial Review in Indonesia: Between Civil Law and Accountability? A Study of Constitutional Court Decisions 2003-2005" (PhD dissertation, Law Faculty, Melbourne University, 2007)

117 See, for example, Zainal Hoesein, Judicial Review Di Mahkamah Agung RI: Tiga Dekade Pengujian Peraturan Perundang-Undangan (Jakarta: RajaGrafindo Persada, 2009); and Ni'matul Huda, Problematika Pembatalan Peraturan Daerah (Yogyakarta: FH UII Press, 2010).

${ }^{118}$ Butt, "Regional Autonomy and the Proliferation of Perda in Indonesia."
} 


\section{Case Study: "Prohibition" Perda}

Our research uncovered only two judicial review decisions in which the Supreme Court declared invalid provisions of so-called "Perda Syariah" —regional laws inspired by Islamic norms. Neither of these Perda explicitly purported to introduce Islamic norms. Rather, they sought to prohibit the sale of alcohol. In the first case, the Perda challenged was Kuningan District Perda No. 29 of 2001 on the Prohibition and Regulation of Alcohol. ${ }^{119}$ In the second, Jambi City Perda No. 3 of 2008 on the Prohibition on the Sale and Distribution of Alcoholic Beverages was challenged. ${ }^{120}$ The applicants were small-scale restaurateurs and business owners who sold beverages containing between 1 and 5 percent alcohol. The applications in these two cases were very similar save for geographical references. This we attribute to both sets of applicants being represented by the same lawyer (Dr. E. Maman Suryaman).

In both cases, the applicants argued that the Perda conflicted with Presidential Decision No. 3 of 1997 on Monitoring and Controlling Alcoholic Beverages. Article 3(1) of this decision classified alcoholic beverages into three categories based on the concentration of alcohol in the drink. Beverages containing up to 5 percent alcohol fell into Category A, those with between 5 and 20 percent were in Category B, and beverages with between 20 and 55 percent, Category C. Article 3(2) provided that Category B and C beverages were "controlled goods" (dalam pengawasan), but did not mention Category A beverages. The applicants argued that because the decision did not stipulate that Category A beverages were controlled goods, the effect of the decision was to make the production, distribution, sale, and consumption of Category A beverages unrestricted.

The decision and reasoning of the Court in both cases were very similar, perhaps because one judge-Justice Prof. H. Ahmad Sukardja-served on the three-judge panel in both cases. The Court accepted the applicants' primary arguments, deciding, in effect, that these Perda could not restrict or prohibit the distribution or sale of drinks containing 5 percent or less of alcohol, because the Presidential Decision did not seek to impose these restrictions or prohibitions. In these two cases, the Supreme Court invalidated Article 3(2) of both impugned Perda, which sought to prohibit the distribution of these weaker alcoholic beverages. The Supreme Court also invalidated Article 4 of both Perda, which excluded hotels with ratings of three stars or more from the prohibition, allowing them-but not other hotels-to sell alcohol.

In these cases, the Supreme Court has demonstrated a willingness to strike down regulations that some Islamic groups appear to support strongly, unlike in the Tangerang prostitution Perda case mentioned above. This is, in our view, quite significant given that the Court could have legitimately thrown out these cases on some of the procedural grounds mentioned above. Notably, the applications for review were lodged "out of time" - that is, not within 180 days of the enactment of the impugned Perda-and so that Court could have refused to accept the application for hearing, ${ }^{121}$ as it has done in other cases mentioned above. Also, the Perda were struck

\footnotetext{
119 Supreme Court Decision No. 20.P/HUM/2002.

${ }^{120}$ Supreme Court Decision No. 25.P/HUM/2008.

${ }^{121}$ In Supreme Court Decision No. 20.P/HUM/2002, the applicants challenged Perda of Kuningan District No. 29 of 2001 together with Kuningan District Head Decision No. 339/KPTS-401-BK/ 2002 Concerning
} 
down for being inconsistent with a Presidential Decision, even though, as we discuss below, the Constitution only grants the Supreme Court jurisdiction to review laws below the level of statute for compliance with statutes.

These cases also appear to present scholars with material that could spark scholarly debate about inconsistency, the need for which we outlined above. The Perda that were invalidated did not contravene any express stipulation, duty, mandate, or prohibition in the higher-level law. Instead, the Court found that the Perda were inconsistent with the Presidential Decision because they purported to control goods that the regulation did not designate as controlled goods. In effect, the Court decided that, by regulating similar goods but not regulating the particular goods in question (Category A beverages), the higher-level law had implicitly "covered the field," thereby prohibiting lower-level laws from further regulating Group A beverages. In this way, the Court found that the Perda "added to" and "modified the substance of the principal regulation." 122

However, the case did not address important issues, two of which we mention here. First, the Court did not, in its published reasons, address the possibility that the Presidential Decision and the Perda were not, in fact, inconsistent. In our view, the Court could have construed the Presidential Decision as purporting to regulate the distribution and sale of only Category $B$ and $C$ beverages. Given that the Presidential Decision did not classify Category A beverages as "controlled goods" and, therefore, did not seek to regulate them in Article 3, the Decision could be interpreted as leaving them "open" and, therefore, subject to regulation by a local government. In other words, because the Presidential Decision did not regulate the distribution or sale of Category A beverages, the path is clear for local governments to do so.

The second issue relates to the Court's invalidation of the Perda for adding to or modifying the Presidential Decision. Article 136(3) of the 2004 Regional Governance Law states that "Perda are to expand upon higher-level law by taking into account the unique features of the region." Unless the higher-level law explicitly provides discretion to local governments, it is difficult to see how adapting prescriptions of higher-level laws to unique local circumstances can be achieved without modifying, adding to, or at least stretching that higher-level law. The Supreme Court provided no guidance on this point and, therefore, quite apart from the limited "precedential" value of Supreme Court decisions, its future approaches to this issue remain unclear.

the Establishment of a Team for the Supervision and Regulation of the Distribution of Alcohol. The Perda was enacted on December 19, 2001, and the application, which was dated August 27, 2002, was registered at the Supreme Court on September 20, 2002. This would have ordinarily put the application outside the 180-day time period. However, the Court held that the Perda had only become "effective" since the promulgation of the Kuningan District Head Decision establishing the supervision team, issued on July 12, 2002. The Court, therefore, counted the relevant time period as from July 12, 2002, to August 27, 2002 (when the application was first made, but before it was registered). Perda of Jambi City No. 3 of 2008, which was the subject of Supreme Court Decision No. 25.P/HUM/ 2008, was enacted on March 4, 2008. The application was registered at the Supreme Court on September 2, 2008. That is 182 days after the enactment of the challenged instrument. However, the Court held, without further explanation, that this was within the 180-day time period. The application was dated August 25, 2008-175 days after the enactment of the Perda-and perhaps this influenced the Court in allowing the application.

${ }^{122}$ See Supreme Court Decision No. 05.P/HUM/ 2005 at p. 23. 
These two cases appeared likely to inspire a raft of similar challenges. Many local governments have sought to restrict the production, distribution, sale, and consumption of alcohol in very similar terms to those of the Perda partially invalidated in these two cases. ${ }^{123}$ So far as they purported to restrict the sale and consumption of Category A beverages, they were presumably susceptible to Supreme Court invalidation on the same basis. Judicial review of these Perda may previously have been blocked by the 180-day rule, but, as mentioned, the Supreme Court has abolished this rule.

In a recent case, however, the Supreme Court has invalidated the very Presidential Decision (No. 3 of 1997) that it had found the Kuningan and Jambi Perda to violate. ${ }^{124}$ At the time of writing, the Court's decision had not yet been published on the Court's website. But as reported in the media, the Court's reason for finding the Presidential Decision invalid was that many of the higher level laws from which it purported to draw its authority-including an old 1971 Regional Governance Law-had been replaced. ${ }^{12}$ This left the Presidential Decision itself without higher legal authority, rendering it invalid.

There is nothing to stop regional governments from re-enacting their Perda to prohibit the production, distribution, sale, and consumption of Category A alcoholic beverages, however. Indeed, the MOHA appears to accept that some regional governments might now even prohibit the sale and consumption of alcoholic beverages altogether. In response to the Supreme Court's decision, the Home Affairs Minister simply expressed his hope that regional governments regulate alcohol "very wisely" so as "not to damage social life." ${ }^{126}$ In the meantime, the minister has proposed that a national Bill on Alcohol be prepared, ${ }^{127}$ which could formally override these prohibition Perda.

\section{Part IV: The Future of Judicial Review in Indonesia}

During our research, some legal commentators and government officials suggested that the Constitutional Court take over all judicial review cases. The Constitutional Court has been hearing constitutional review cases for almost a decade and, during the tenure of its first two chief justices, Jimly Asshiddiqie and Mahfud MD, it built a strong reputation for professionalism and has developed significant bodies of jurisprudence. However, the reputation of the Court plummeted in late 2013, when its third chief justice, Akil Mochtar, was arrested for allegedly taking bribes to fix the outcome of electoral disputes heard before the Court. Even though there have been few, if any, allegations of impropriety in the Constitutional Court's handling of judicial review

\footnotetext{
${ }^{123}$ See, for example, Perda of Maros District No. 9 of 2001; Perda of Tangerang City No. 7 of 2005; Perda of Indramayu District No. 7 of 2005 (as amended by Perda of Indramayu District No. 15 of 2006); Perda of Banjarmasin City No. 6 of 2010; Perda of Jambi City No. 7 of 2010; Perda of Bandung City No. 11 of 2010. ${ }^{124}$ Supreme Court Decision No. 42.P/HUM/2012. The application was lodged by the Islamic Defenders Front (Front Pembela Islam, FPI) on October 10, 2012, and decided on June 18, 2013, by H. Yulius, Dr. HM. Hary Djatmiko and Dr. H. Supandi.

125 "Inilah Alasan MA Batalkan Keppres Miras," Hukumonline, July 10, 2013.

${ }^{126}$ Wahyu Wening, "Kepres Dicabut MA, Mendagri Usul Perlunya UU Miras," Jurnal Nasional, July 8, 2013

${ }^{127}$ Ibid.
} 
cases (the types of public law cases that we have discussed in this article, except with a focus on the Supreme Court), whether the Court can regain its reputation for professional decision making remains to be seen.

In any event, at present, its constitutionally mandated function is quite narrow. It can only review statutes (laws enacted by Indonesia's national parliament) to determine if they accord with the Constitution. ${ }^{128}$ This means that a constitutional amendment would probably be required to grant the Constitutional Court authority to review regional bylaws for compliance with higher-level laws. Amending the Constitution in Indonesia is, like in many other countries, a highly fraught political process that is likely to take years, if it occurs at all. However, we argue that the Constitutional Court has at its disposal at least two avenues through which it could, without exceeding its constitutional mandate, review bylaws, albeit only for compliance with the Constitution, as opposed to other "higher" laws, such as regulations and statutes.

First, in recent cases, the Court has sought to assess the constitutionality of not only the substance of statutes, but also their implementation. ${ }^{129}$ Following these cases, the Court could, if requested in a future case, assess the constitutionality of the implementation of the 2004 Regional Governance Law-which requires that bylaws meet various requirements, including compliance with higher-level laws and the public interest. The Court has, in several cases, applied Article 28D(1) of the Constitution ("Every person has the right to legal recognition, guarantees, protection, and certainty that is just, and to equal treatment before the law") to find that statutes that are ambiguous or inconsistent with other laws are unconstitutional. ${ }^{130}$ Using this ground to assess the implementation of the 2004 Regional Governance Law, the Court might be able to declare that a Perda which is inconsistent with a national higher-level law is constitutionality invalid on grounds of legal uncertainty.

Second, the Constitutional Court could arguably employ its constitutional power to "resolve jurisdictional disputes between state institutions whose powers are granted by the Constitution" (Article $24 \mathrm{C}(1)$ of the Constitution) to allow it to review bylaws against higher laws. The Court has, thus far, heard very few of these jurisdictional disputes. Constitutional Court Regulation 08/PMK/2006 on Guidelines for Constitutional State Institution Jurisdiction Dispute Proceedings provides a list of institutions that can bring these types of cases before the Court. They include the national parliament, the president, and local governments (Article 2) that consider their constitutional jurisdiction ${ }^{131}$ to have been "taken, reduced, impeded, ignored and/or damaged by another state institution" (Article 3(1)). It is at least arguable that, when a local government issues a bylaw that contravenes a law issued by the national parliament or the executive, which the president heads, such a jurisdictional dispute

${ }^{12 s}$ Article $24 \mathrm{C}$ of the Constitution.

${ }^{129}$ See, for example, Constitutional Court Decision No 5/PUU-IX/ 2011.

${ }^{130}$ Butt and Lindsey, The Indonesian Constitution: A Contextual Analysis.

${ }^{131}$ Constitutional Court Regulation No 08/PMK/2006 stipulates in Art 1(6) that an institution's "constitutional jurisdiction" is its "jurisdiction that can take the form of a power/right and a task/obligation which is given by the Constitution." 
occurs. ${ }^{132}$ Similarly, a jurisdictional dispute arguably occurs when the president purports to invalidate a bylaw issued by a regional government.

The main impediment to the Constitutional Court using this jurisdiction to review bylaws appears to be as follows. While the Constitution establishes national and local governments and, in broad terms, their powers, ${ }^{133}$ the details of the relative jurisdiction of national and regional governments are delineated in the 2004 Regional Governance Law. On the other hand, the Constitution does specify that the jurisdictions of various government institutions can be further regulated by statute. The question becomes whether this constitutional delegation is sufficient to enliven this aspect of the Constitutional Court's jurisdiction. To our knowledge, this argument has not yet been put to the Court. A significant limitation, though, is that only state institutions-and not aggrieved citizens-can avail themselves of this jurisdiction.

Though it might be able to review questionable Perda through these two avenues, in fact, the Constitutional Court has very little incentive to encumber itself with this burden. The Court already performs the critical functions of reviewing the constitutionality of statutes and resolving electoral disputes, ${ }^{134}$ responsibilities that take up most of the time of the Court's nine judges. Assuming responsibility for reviewing Perda might overwhelm it, perhaps leading to a reduction in quality of its decision making in these other categories of cases.

In the foreseeable future, then, it is highly likely that the Supreme Court will continue to handle these review cases. We argue that the Court could empower itself to mediate more effectively legal disputes between tiers and institutions of government. It could begin doing this by addressing the weaknesses we identified with the way it currently exercises judicial review. This would require the Court to recognize the fundamental differences between judicial review cases and the other types of cases it hears. Unlike civil and criminal cases, for example, judicial review cases do not affect only the legal positions of the parties, with limited applicability to others unless the case develops a principle of jurisprudence, as discussed above. In judicial review cases, the Supreme Court's decisions have general application. That is, if the Court decides to invalidate a provision of a bylaw, or an entire bylaw, then the invalidated provision or bylaw is no longer valid-to the benefit or detriment of all citizens to whom the bylaw would otherwise have applied. In addition, the Court hears civil and criminal cases only on appeal, relying on evidence and submissions made in lower courts as well as on appeal. Judicial review cases, by contrast, are heard at first and final instance by the Supreme Court.

First, the Supreme Court could accommodate oral submissions in judicial review cases, allowing the parties to respond directly to each other's arguments, and questions from the judges, in open court. In our view, the general public arguably has a greater interest in judicial review cases-in which important matters of public law are often

\footnotetext{
${ }^{132}$ Article 1(7) of Constitutional Court Regulation No 08/PMK/ 2006 specifies that a dispute is a "dispute [perselisihan] or difference of opinion related to the implementation of jurisdiction between two or more state institutions."

${ }^{133}$ See, for example, Chapter III and Article 18 of the Constitution.

${ }^{134}$ Simon Butt, Indonesian Constitutional Court Decisions in Regional Head Electoral Disputes, CDI Policy Paper (Canberra: Centre for Democratic Institutions, Australian National University, 2013).
} 
aired and decided-than they do in other cases the Court hears (unless, of course, they are litigants in those other cases). The Court's decisions-whether to annul or maintain a law-directly affect citizens because citizens are obliged to follow the law. In our view, then, the public has a particular interest in hearing both the arguments made before the Court and the Court's response to them. Yet judicial review cases are decided almost entirely behind closed doors. This removes transparency from the process and prevents judges from testing the submissions of the parties.

Further, in most other types of cases the courts hear, oral submissions have already been made and witness testimony heard in the lower courts. The function of the Supreme Court in these cases is primarily to settle matters of law ${ }^{1.5}$-particularly to ensure that the lower courts have made no legal errors-since the facts and legal arguments of the parties have already been introduced in the lower courts.

Second, the Court should, in judicial review cases, allow itself to issue injunctions to prevent the application of the impugned Perda for the duration of proceedings. The Court should also give its decisions retrospective effect so that those affected by a government action performed under a Perda the Court declares invalid can be compensated or the injustices resulting from the improper law otherwise remedied. Unless it does so, local governments can issue and apply bylaws that clearly breach human rights or higher order laws without fear that they might be prevented from applying them while the Supreme Court considers the case or that they might ever be required to compensate for those breaches. Individual citizens, therefore, have few incentives to lodge judicial applications with the Court, because they themselves will usually get no benefits, even from a favorable decision. The best they can hope for is that the impugned law will not be used against other citizens in the future.

Third, the Supreme Court should also publish all of its judicial review decisions, since these decisions relate to public issues and are critical to the integrity of regional autonomy and the maintenance of Indonesia's legal order. This would not significantly increase the Court's administrative burden given that, as mentioned, judicial review cases take up only a small proportion of its workload. Increased publication might also assist in the development of doctrine and jurisprudence.

Many of these changes can be made with relatively minor changes to the Court's judicial review procedures. Most of them are regulated in Supreme Court Regulations (Peraturan Mahkamah Agung), Practice Notes (surat edaran), or by "custom." Changing or removing the practices should only require amending or revoking these instruments or issuing new ones. The Court can do this unilaterally. Indeed, the Court removed the 180-day time limit for the lodgment of judicial review applications, mentioned above, simply by issuing a Supreme Court Regulation.

But what about the apparently impassable constitutional obstacle? As mentioned, the Constitution (and Article 31(1) of Law No. 14 of 1985 on the Supreme Court itself) permits the Supreme Court to review only lower-level laws, including Perda, as opposed to statutes. In other words, according to the Constitution and the 1985 Supreme Court Law, the Court lacks power to assess the compliance of bylaws with other laws on the hierarchy, such as Presidential Regulations and Government

135 See Article 30(1) of Law No. 14 of 1985 on the Supreme Court as amended by Law No. 5 of 2004. 
Regulations, or even the Constitution, including its Bill of Rights. The Court has, in fact, rejected applications for judicial review of bylaws as against government regulations, at least partly on this ground. ${ }^{136}$

The Court's stance on this fundamental issue has been far from consistent. Successive regulations on judicial review procedures issued by the Supreme Court Chief Justice since 1993 appear to have ignored these constitutional and statutory restraints. The regulations have declared that Supreme Court judicial review applications "are to be brought against a legal instrument suspected of being inconsistent with a higher level legal instrument." ${ }^{137}$ Indeed, the Court has, in fact, struck down Perda for conflicting with government regulations and presidential decisions in three cases we studied. ${ }^{138}$

The result is significant uncertainty about whether the Supreme Court will confine itself to reviewing compliance with statutes. Yet consistency is not the only problematic aspect of the Court's approach. Clearly, many judges of the Supreme Court either simply reject that the Court's general judicial review jurisdiction is limited by the Constitution and the Supreme Court Law or have found a legally acceptable way to, in effect, circumvent the limitation. It may be, for example, that some judges believe that the 2004 Regional Governance Law-a statute-prohibits the enactment of Perda that contradict higher-level laws ${ }^{139}$ and that this includes national government, presidential, and ministerial regulations and decisions. A bylaw would, therefore, be inconsistent with the 2004 Law if it breached a "higher" law, even if that higher-level law were not a statute. ${ }^{140}$

Similarly, judges might reason that Article 7 of the Lawmaking Law, which provides that the legal force of a law is commensurate with its position on the hierarchy of laws, justifies its apparent circumvention of the constitutional limitation of its jurisdiction. As the Elucidation to this provision states, a lower-level law must not conflict with a higher-level law. According to at least one decision of the Supreme Court, lower-level laws cannot, therefore, modify the substance of a higher-level law and cannot add to, detract from, or insert a new stipulation. ${ }^{141}$ A Perda would, therefore, arguably be in conflict with Article 7 of the Lawmaking Law (a statute) if it were inconsistent with any law higher than Perda on the hierarchy of laws.

In our view, the problem is not necessarily whether the Court has sought to circumvent this restriction. Rather, it is that the Court has not, in any of the judicial review decisions we obtained for this research, attempted to give any legal explanation for circumventing the limitation on its jurisdiction, let alone a convincing one. But this is, as we have shown in this article, indicative of the Supreme Court's general approach in judicial review cases, and evidence of its reluctance to engage in any detail with the legal "merits" of any case, at least in its written judgment. We suspect that the Court

\footnotetext{
${ }^{136}$ See, for example, Supreme Court Decision No. 19.P/HUM/ 2002.

${ }^{137}$ Article 2(2) of Supreme Court Regulations No. 1 of 2004 and 2011; Article 3(1) of Supreme Court Regulation No. 1 of 1993.

${ }^{138}$ Supreme Court Decision Nos. 01.P/HUM/2001, 20.P/HUM/2002, and 25.P/HUM/ 2008.

1392004 Regional Governance Law Art 136(4).

${ }^{140}$ Parsons and Mietzner, "Sharia By-laws in Indonesia."

${ }^{141}$ Supreme Court Decision No. 05.P/HUM/2005 at p. 23.
} 
will not function as an effective mediator between governments and institutions in decentralized Indonesia until it provides more clarity on fundamental issues such as these, or at least until Indonesian legal scholars develop more instructive doctrine on the theory and practice of judicial review in Indonesia. This is unfortunate because, after decades of authoritarian rule under which the law and its operation were dominated by politics and corruption, the Court appears to be missing a real opportunity to establish law as an effective check on the exercise of government power. 